\title{
First report of Pythium recalcitrans infecting flue-cured tobacco
}

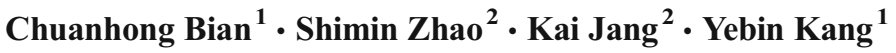

Received: 3 November 2015 / Accepted: 20 March 2016 / Published online: 29 March 2016

(C) Australasian Plant Pathology Society Inc. 2016

\begin{abstract}
In July 2014, an unknown Pythium sp. was isolated from the rhizosphere soil of flue-cured tobacco (Nicotiana tabacum) in Luoyang of China. Based on morphological characteristics and phylogenetic analysis of Inter Transcribed Spacer sequences, the pathogen was identified as Pythium recalcitrans Moralejo. The result of the pathogenicity test showed that Pythium recalcitrans could infect the seedlings of flue-cured tobacco.
\end{abstract}

Keywords Pythium recalcitrans $\cdot$ Flue-cured tobacco · Pathogenicity

Luoyang is a high quality tobacco production area in China. It belongs to the warm temperate continental monsoon climate, therefore having four distinct seasons. It experiences a large temperature difference annually with long hours of sunshine in the summer months. It is characterised with varied topography including hills, mountains and numerous rivers. Each year, nearly 20000 ha of flue-cured tobacco are planted in hilly land. However, the diseases of flue-cured tobacco, caused by the lack of good cultivation management greatly influence the quality of flue-cured tobacco.

Yebin Kang

18530056703@163.com

Chuanhong Bian

13101795325@163.com

1 Laboratory of Plant Immunology, College of Forestry, Henan University of Science and Technology, Luoyang, Henan 471003 , China

2 Luoyang Tobacco Branch Company of Henan Tobacco Company, Luoyang, Henan 471023, China
The genus Pythium was first established by Pringsheim in 1858 and since then, members of this genus have been widely described throughout the world (Van der Plaats-Niterink 1981). Pythium species are commonly found in water and its surface sediment, sand, field soils and residual dead roots of previous crops (Mathew et al. 2003). Many Pythium spp. are plant pathogens that are found attacking any part of their host plant, mainly infecting succulent tissues, juveniles, seeds and seedlings, causing root rots and damping-off diseases (Hendrix and Campbell 1973). Damping-off of tobacco seedlings is known to be caused by $P$. aphanidermatum (Fajola and Alasoadura 1974). Additionally there are reports of $P$. ultimum and $P$. debaryanum infecting seedlings of flue-cured tobacco (Wang 1997), Pythium myriotylum infecting the seedlings and stems of tobacco (Sigobodhla et al. 2010), Pythium dissotocum causing yellow stunt disease of tobacco in Southern Parts of Brazil (Corrêa et al. 2011), and Pythium vexan causing the shank rot of flue-tobacco (Miao et al. 2014).

Recently, with the influence of continuous cropping in Luoyang, root disease of flue-cured tobacco has become common and it is becoming increasingly more difficult to control. The stem base of diseased tobacco plants become dark brown without an obvious border, and the piths become brown and divided into the disc shape. In order to determine the species of pathogens in the rhizosphere soils of flue-cured tobacco, soil samples were collected from different tobacco fields after tobacco had been transplanted 120 days in the Luoyang municipality. Pythium spp. were isolated by a baiting technique where soil was placed in a sterile Petri dish and thoroughly mixed with $30 \mathrm{~mL}$ sterile distilled water. Petals of Chinese rose (Rosa chinensis) that had previously been soaked in Penicillin $(50 \mathrm{U} / \mathrm{mL})$ and Streptomycin $(50 \mathrm{U} / \mathrm{mL})$ solution for an hour were then placed on the surface of the soil solution, and incubated at $25{ }^{\circ} \mathrm{C}$ for three days. Following incubation in the soil-solution, the infected Chinese rose petals were washed in running tap water for 
20 min, treated with $0.5 \%$ Clorox solution for $30 \mathrm{~s}$, rinsed three times with sterile distilled water, blotted dry with sterile filter paper, placed on cornmeal agar (CMA) (Van der PlaatsNiterink 1981) medium with penicillin $(50 \mathrm{U} / \mathrm{mL})$ and streptomycin $(50 \mathrm{U} / \mathrm{mL})$ and incubated at $25^{\circ} \mathrm{C}$. After for two to three days putative, Pythium isolates were transferred as hyphal tips to oatmeal agar (OA) (Bruchart and Lorbeer 1982).

Tobacco seedlings were cultivated in tobacco nursery substrate (Jiangxi Tianhui Brand) mixed with an equal volume of soil in seedling trays with conditions of $25^{\circ} \mathrm{C}, 12 \mathrm{~h} / 12 \mathrm{~h}$ day/ night cycles the in glass house. Healthy seedlings were transplanted into $8 \mathrm{~cm} \times 10 \mathrm{~cm}$ nutrition bowls for trails when they had eight leaves. To confirm pathogenicity, a $10 \mathrm{~mm}$ diameter OA disc, containing active mycelium and sporangium of the isolate, was wound-inoculated on the stems base of 15 healthy ten-leaf stage flue-cured tobacco seedlings (variety: yuyan six) growing in an $8 \times 10 \mathrm{~cm}$ nutritive bowl in a glass house with conditions of $25^{\circ} \mathrm{C}, 12 \mathrm{~h} / 12 \mathrm{~h}$ day/ night cycles. Fifteen control plants were inoculated with OA discs without the isolate. The inoculation point was moisturised using a cotton wool ball soaked with sterile distilled water on the surface. The seedlings were observed for symptoms

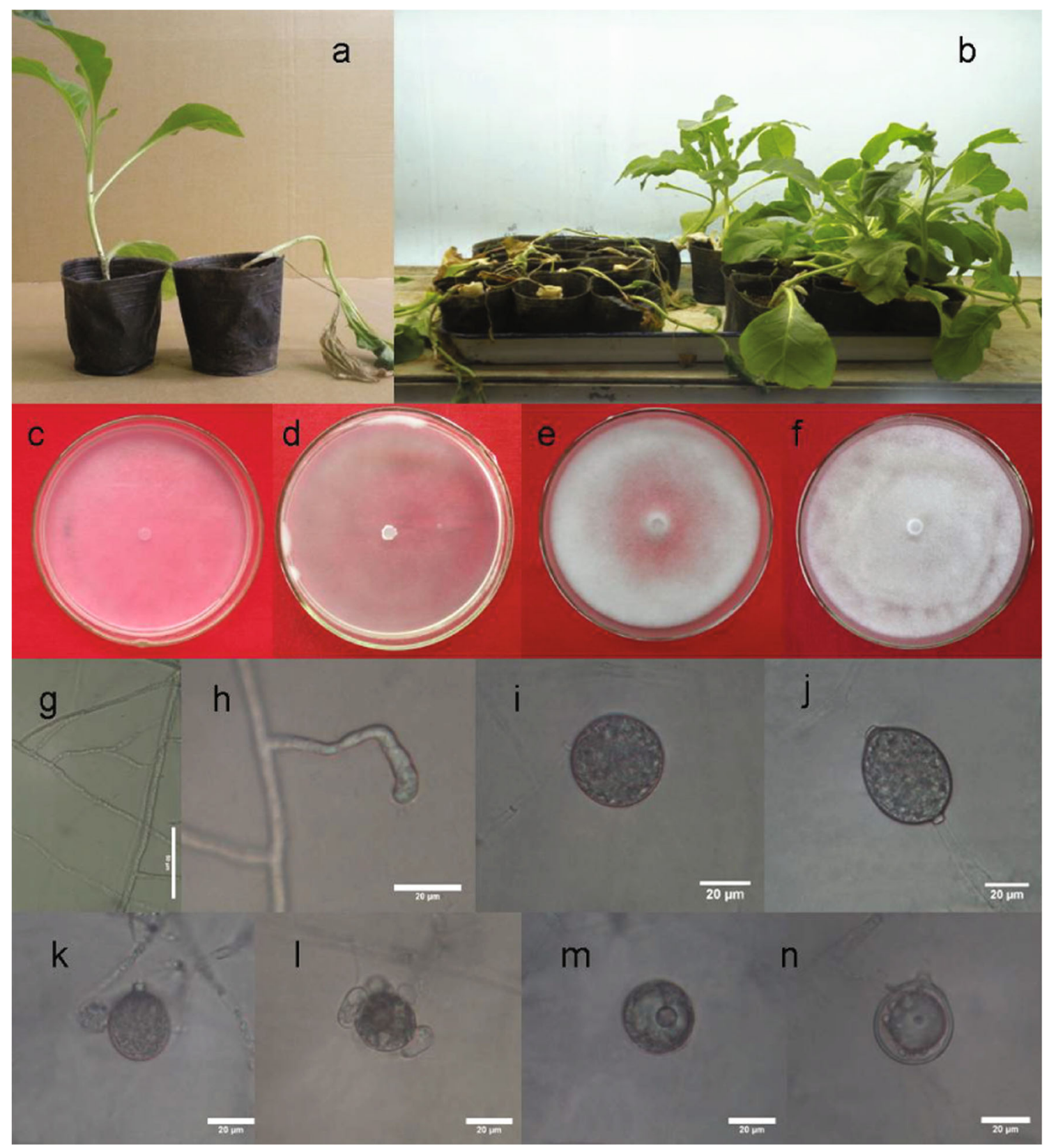

Fig. 1 Symptoms of flue-cured tobacco infected by Pythium recalcitrans and the morphology of Pythium recalcitrans. a one healthy seeding and one infected by Pythium recalcitrans. b healthy seedlings and infected by
Pythium recalcitrans. $\mathbf{c}, \mathbf{d}, \mathbf{e}$ and $\mathbf{f}$ culture features on OA, CMA, PCA and PDA. $\mathbf{g}$ hyphae. $\mathbf{h}$ appresorium. $\mathbf{i}$ and $\mathbf{j}$ sporangium. $\mathbf{k}, \mathbf{l}, \mathbf{m}$ and $\mathbf{n}$ oogonia, antheridia, oogonium 
every day following inoculation. The watery brown lesions could be observed on the shank of the seedlings after three days. Over time, brown lesions slowly expanded, the leaves of seedlings wilted; the seedlings fell down and even died. Seven days later, 11 seedlings had died, two seedlings became wilted and one seedling had an emerging brown lesion. However, all plants in the control tests remained healthy. The isolate was reisolated from the symptomatic tobacco seedlings.

The colony characteristic of the isolate used in the inoculations was observed on CMA, OA, carrot agar (CA) and potato dextrose agar (PDA) medium, respectively (Balghouthi et al. 2013). The morphological structure was observed microscopically by using standard keys after incubating for one or two weeks at $25{ }^{\circ} \mathrm{C}$ in the dark (Babai-Ahary et al. 2004; Dick 1990). On CMA, colonies were non-patterned with a vague outline, mycelium submerged, diffuse and slightly dendroid. On OA, colonies were non-patterned to slightly radiate with a smooth outline, aerial mycelium near the margins. On CA, colonies were non-patterned with a smooth outline, loose aerial mycelium covering medium surface. On PDA, colonies were non-patterned with a smooth outline, tight aerial mycelium covering medium surface. The daily growth rate was $22.2 \pm 1 \mathrm{~mm}$, $16.8 \pm 1 \mathrm{~mm}, 15.6 \pm 1 \mathrm{~mm}$, and $20.6 \pm 1 \mathrm{~mm}$ on OA, CMA, CA and PDA medium at $25^{\circ} \mathrm{C}$, respectively. The hyphae were hyaline, smooth, straight or slightly undulate and, 4.3 (2.57.2) $\mu \mathrm{m}$ wide. The hyphal branch system was short and dendroid. The hyphal contents were observed to evacuate after one week with many cross-septa then remain visible. Appressoria were abundant on the plate floor; there were large, simple, clavate, falcate or sometimes irregularly shaped on CA. Sporangium were abundant within one week on OA, forming terminally on hyphal branches or mostly intercalary, spherical to subglobose with a diameter of $25.0 \pm 2.6(10.9-38.5) \mu \mathrm{m}$. A few were doliiform to limoniform, or cylindrical on the main hyphae. Zoospores were not observed under standard conditions in distilled water and soil extract. Sexual structures were not observed in agar culture. However, oogonia formed readily and abundantly for all isolates when placed on grass blades incubated on distilled water. These oogonia were smooth walled, spherical to subglobose with a diameter of $24.0 \pm 2.6$ (18.4-32.5) $\mu \mathrm{m}$. Antheridia were diclinous when the stalk insertion was discernible, sometimes with a broadened attachment, mostly crook-necked and multiple. Up to seven seen per oogonium. Oospores were spherical, smooth, 21.0 $\pm 2.6 \mathrm{~mm}$ diam, both plerotic and aplerotic. Many aborted oospores present in the colonised grass blades (Fig. 1).
Fig. 2 Molecular phylogenetic analysis of isolate P38 with Pythium spp. and Phytophthora spp. obtained from GenBank by neighbor-joining method based on the ITS sequences. Bootstrap values after 1000 replicates were expressed as percentages

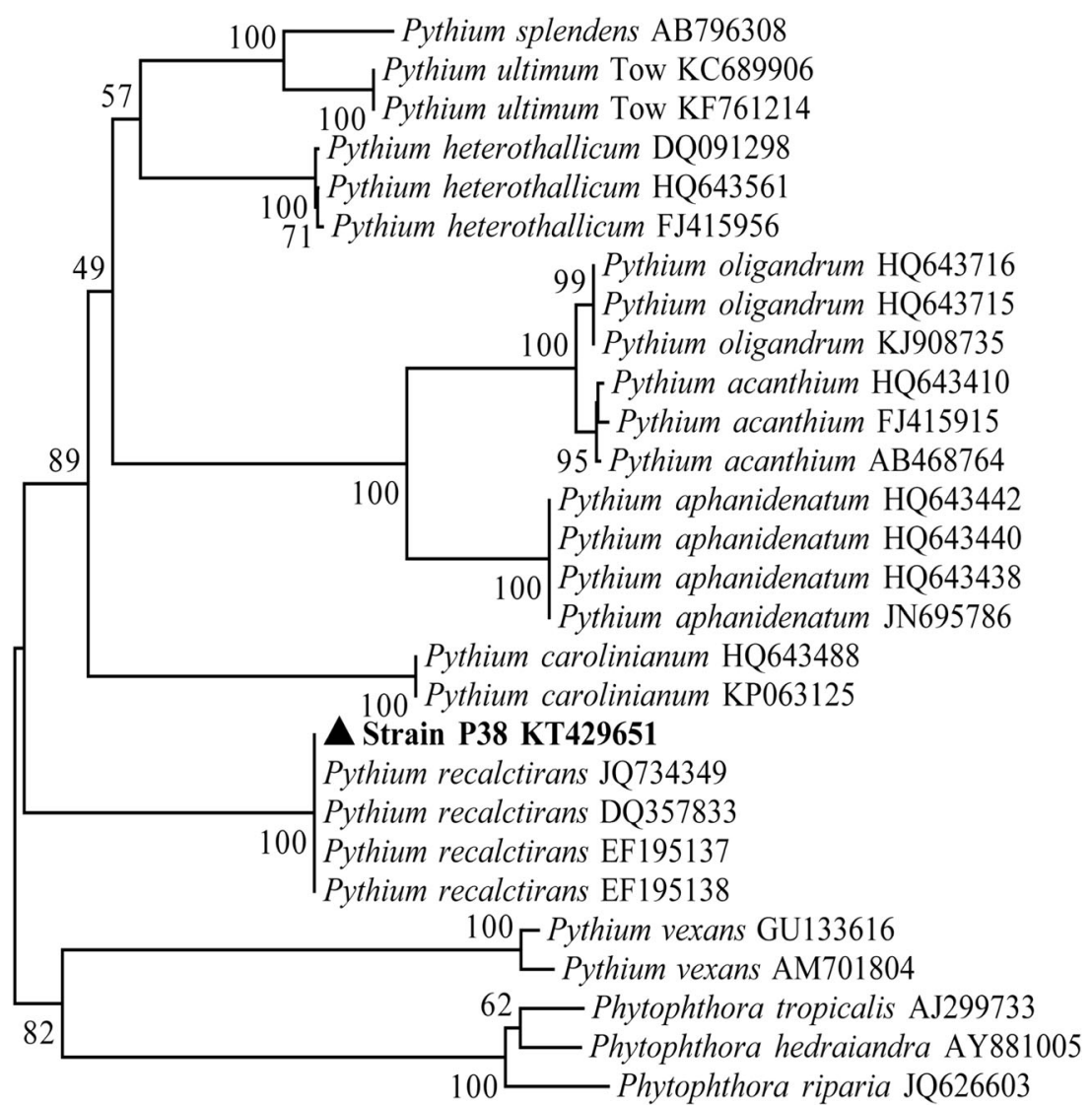

0.05 
The isolate P38 was reconfirmed by sequencing and phylogenetic analysis. DNA was extracted using the method described by Raeder and Broda (1985). The internal transcribed spacer sequence was amplified using the universal primers ITS4 (5'-TCCTCCGCTTATTGATATGC-3') (White et al. 1990) and ITS1 (5'-TCCGTAGGTGAACCTGCGG-3') (Paul et al. 1999). The sample was denatured at $94{ }^{\circ} \mathrm{C}$ for $5 \mathrm{~min}$, followed by 30 amplification cycles $\left(94^{\circ} \mathrm{C}\right.$ for $45 \mathrm{~s}$, $55^{\circ} \mathrm{C}$ for $45 \mathrm{~s}, 72^{\circ} \mathrm{C}$ for $\left.105 \mathrm{~s}\right)$ and a final extension $\left(72^{\circ} \mathrm{C}\right.$ for $10 \mathrm{~min}$ ) (Petkowski et al. 2013). The amplified PCR product was sequenced at the Sangon Biotech (Shanghai, China) Co., Ltd. The production of ITS amplification was $875 \mathrm{bp}$ and submitted in GenBank (KT429651). The sequence was blasted with the sequences deposited in GenBank nucleotide database and the results showed greater than $99 \%$ similarity to sequences of Pythium recalcitrans (DQ357833, EF195137, EF195138, JQ734349) (Moralejo et al. 2008; Lu and Hao 2014). For the phylogenetic analysis, a total of 30 sequences of Pythium and Phytophthora species obtained from GenBank and P38 were used to construct the phylogenetic tree. Nucleotide sequences were analysed using MEGA version 6 (Tamura et al. 2011) for neighbor-joining method, using the Kimura-2-parameter nucleotide substitution model. Bootstrap values were obtained from 1000 bootstrap replicates (Fig. 2). The isolate P38 clustered in a clade with known isolates of $P$. recalcitrans. Therefore, the pathogen of flue-cure tobacco was identified as $P$. recalcitrans based on the morphological characters as well as the ITS1-5.8S-ITS2 sequence. The strain P38 (P. recalcitrans) was deposited at the China General Microbiological Culture Collection centre and numbered as CGMCC3.17856.

Pythium recalcitrans was first described as a new species collected from grapevine roots in South Africa and roots of common beet in Majorca, Spain (Moralejo et al. 2008). In China, it was first described as a new species collected from soils in vegetable fields (Long 2014). Pythium recalcitrans is a soil inhabitant associated with root infection of terrestrial plants, and has a wide host-range, geographic distribution and ecological niche. Pythium recalcitrans was also reported causing cavity spot of carrot in Michigan (Lu and Hao 2014). To our knowledge, this is the first report that $P$. recalcitrans could infect flue-cured tobacco.

\section{References}

Babai-Ahary A, Abrinnia M, Majidi Heravan I (2004) Identification and pathogenicity of Pythium species causing damping-off in sugarbeet in northwest Iran. Australas Plant Pathol 33:343-347
Balghouthi A, Jonathan R, Gognies S, Mliki A, Belarbi A (2013) A new species, Pythium echinogynum, causing severe damping-off of tomato seedlings, isolated from Tunisia, France, and India: morphology, pathology, and biological control. Ann Microbiol 63:253-258

Bruchart WL, Lorbeer JW (1982) Pythium species pathogenic to onion seedlings grow on organic soils in New York. Phytopathology 72 : $469-475$

Corrêa AS, Rocha AB, Willani SA, Dariva JM, Souza MV, Moraes MG (2011) Yellow stunt, a tobacco disease caused by Pythium dissotocum, in Southern parts of Brazil. Plant Dis 95(3):354

Dick MW (1990) Keys to Pythium. UK: University of reading press, school of plant Science, department of botany P.64

Fajola AO, Alasoadura SO (1974) Studies on the damping-off disease of tobacco (Nicotiana tabacum) in Nigeria. Mycopathol Mycol Appl 52:239-249

Hendrix FFJ, Campbell WA (1973) Pythiums as plant pathogens. Ann Rev Phytopathol 11:77-98

Long YY (2014) Pythium DNA, barcode and molecular systematics study (doctoral thesis). Guangxi university, China

Lu XH, Hao J (2014) First report of Pythium recalcitrans causing cavity spot of carrot in Michigan. Plant Dis 99(7):991

Mathew R, Singh KK, Paul B (2003) Pythium campanulatum sp. nov. isolated from the rhizosphere of maize, its taxonomy, ITS region of rDNA, and comparison with related species. FEMS Microbiol Lett 226:9-14

Miao P, Wang HT, Li SJ, Kang YB (2014) First report of two pathogenic fungi on tobacco in Henan Province. Chinese Tobacco Sci 2: $113-116$

Moralejo E, Clemente A, Descals E, Belbahri L, Calmin G, Lefort F, Spies CFJ, Mcleod A (2008) Pythium recalcitrans sp. nov. revealed by multigene phylogenetic analysis. Mycologia 100(2):310-319

Paul B, Galland D, Masih I (1999) Pythium prolatum isolated from soil in the Burgundy region: a new record for Europe. FEMS Microbiol Lett 173:69-75

Petkowski JE, de Boer RF, Norng S, Thomson F, Minchinton EJ (2013) Pythium species associated with root rot complex in winter-grown parsnip and parsley crops in south eastern Australia. Australas Plant Pathol 42:403-411

Raeder U, Broda P (1985) Rapid preparation of DNA from filamentous fungi. Lett Appl Microbiol 1:17-20

Sigobodhla TE, Dimbi S, Masuka AJ (2010) First report of Pythium myriotylum causing root and stem rot on tobacco in Zimbabwe. Plant Dis 94(8):1067

Tamura K, Peterson D, Peterson N, Stecher G, Nei M, Kumar S (2011) Mega:5 Molecular evolutionary genetics analysis using maximum likelihood, evolutionary distance, and maximum parsimony methods. Mol Biol Evol 28:2731-2739

Van der Plaats-Niterink AJ (1981) Monograph of the genus Pythium. Stud Mycol 21:1-242

Wang JH (1997) Distributions and pathogenicity of Pythium spp. Infecting Tobacco in Yunnan Province (In Chinese with English abstract). Journal of Yunnan Agricultural University 12:97-102

White TJ, Burns T, Lee S, Taylor J (1990) Amplification and direct sequencing of fungal ribosomal RNA genes for phylogenetics. In: Innins N, Gelfand D, Sninsky J, White T (eds) PCR protocols: a guide to methods and applications. Part three: genetics and evolution. Academic Press Incorporation, New York 